岡山大学医学部, 解剖学教室 (主任：関教授).

Anat. Inst. d. Med. Fak. Okayama (Vorstand : Prof. M. SEKI).

\title{
二十日鼠の線組系と網內系の紐胞の総数と 総体積の比較.
}

\section{Vegleichung der Gesamtzellzahl und des Gesamtzellvolumens des fibrohistiozytären und Retikuloendothelialsystems des Mauskörpers.}

\section{松井 健 三 Kenzō MATSUI.}

（昭和 25 年 11 月 20 日原稿受附）

線組系は身体至るとてろの器官の队外にある普通の結合組織にある線維 細胞，線組球，組織球，單核球之粘膜飞ある細網細胞を一細胞系之見な し，それに与へられた名である。緗組系細胞が種々の伝染疾患の防禦亡治 癒に甚だ重要な役をなすととが近年制つて来た。しかるに絧勺系はその名

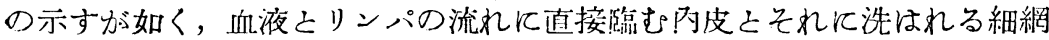
細胞の称であつて，周知の如く伝染疾患の防徱亡治癒に与るけれども，微

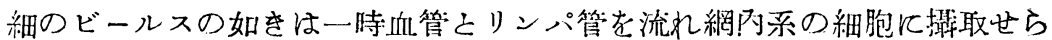
れるてよがあつても，次んで少からぬ部分が速かに管壁を潜つて外に出で て線組系の領域に広り，その諸細胞に捕捉せられることは明かである。

注意すべさは，最近の沢近（1950）の実験であつて，氏は家鬼の皮下に 大腸菌を入れ，3-14日後に皮下組織亡脾の抽出液の殺菌力を比較し，伎 下の線組系細胞の單位体積の殺菌力が脾の細網細胞の\&のの数倍であるて 亡を見たのである。

線組系は上記の如く皮下のみならホ全身に広り，その細胞の総量は趗だ 大であると思はれるが，まだそれを実测したものがなん，ただ一人 Lewis （1929）は約 $200 \mathrm{~g} の$ 白鼠の大腿の皮下西る結命組織の大食細胞，郎ち組 織球を算へ，全身の皮下組織にあるものの総数を 8.55 億，その体積を 3400 $\mathrm{cmm}$ 亡概算し，その数は流血中の全白血球数 1.08 億の約 8 倍なることに注 意した。

私は二十日鼠の皮下のみならす，殆ど全身の線組系の細胞の数之体積を できるだけ精密に計測して，てれを網肑系の主要所在器官なる脾亡肝の同 系細胞のもの之比較するて之を志し，忍耐を以て事に從ひ，大体満足すべ さ成績を得をから，次にてれを報告する。 


\section{I. 材料と方法.}

1. 線組系. 材料亡して生後約 2 月の健常雄性二十日鼠（体重 $24 \mathrm{~g}$ ) を遻び，クロロホルムで殺し，丁算に剃毛し，固定液の澉透を容易ならし める筑に頭部，胸部，腹部の左側に夫々正中線を超えなん程安の大なる 1

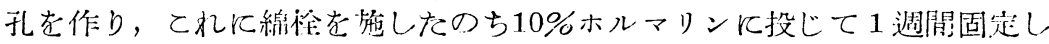
た. 次で $5 \%$ 三塩化醋酸で 2 週間脫石灰し，後肢亡尾を切離し，頭から胴 へかけて，正中線よりやや左側で先狀に切断した。 かくして得た頭之胴の 右半部, 右の上下肢, 星を $0.5-0.9 \mathrm{~cm}$ の厚さ又は長さに切断した。 そして チェロイヂンに包埋し，厚さ $25 \mu$ の䡛続切片を作り，切片を交互にへマト キシリンとエオシンの2 重染色之 Möllendorff の鐵へマテインラック染色 を施した。

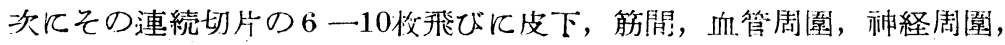

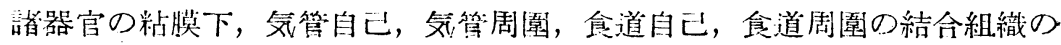
細胞の総数亡その総体積を計测した。その方法を詳しく元へば，先づ至る 所にある結合組織の部分々ヶを，その広さに応じて投射描写裝犆により40 一100倍に，又は描每プリズムにより600倍に扰大して紙に描写した。而 して細胞数を求めるには，描写プリズムにて 600 倍に拡大描写せられた切 片の至る所にある結合組織の一部（例へば皮下等にて），または全部（例 へば小血管周園等にて）の队とある細胞核の数を切片の全厚 $(25 \mu)$ 亿亘 つて算へた，結合組織の一部につき算定する際は，同一結合組織の数所か ら十数所につき同一算宗を行ひ，その平均の治からその結合組織全部の細 肘数を求めた。次に細胞の總体積は，結織細胞の互の限然が明膫でなんの で，個々の細胞体積から之を求めると亡がむつ汸ししん，そこで上記細胞数 を求めたと同榚の方法で，結合組織の一部又は全部队河る結織細胞の像 を全部そのまま切片の種々の高さに於て描写し（高さの数を多くするほど 結果汃確実），その各高さに於ける細胞の総面皘の平均值を求め，てれに 切片の厚さ $(25 \mu)$ を悲じてその部分に於ける結織細胞の總体積とした. ての計测にはまことに大なる辛抱を要したのである。結合組織の一部につ さ算定する際は，上記之同稼闰一結合組織の種々部分につを同一算定を行 ひ，その壮均值からその結合組織全部の結織細胞の總体積を推算した。

描写プリズムを用ひるときには，繁微鏡の固有視野の明るさと描写紙面 の明るさ之の調和がうまく取れなん之，拈笔や細胞数の算定が不可能で ある。そのためには眼を十分喑適応せしめたのち，よく汕者の明るさの調 和を計らなければならない。 
2. 網內系。網队系は代表器官なる脾と肝のみで檢䍒し，前者では細網 細胞，後者では Kuprier 氏星細胞の総数亡総体積艺計測した。

先づ脾は赤血球と白血球を甚だ多く含み，細網細胞は大部分てれに被は

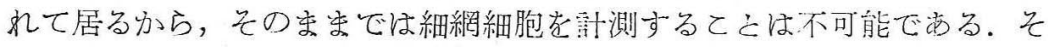
こで二十日鼠の死後直らに開腹して脾を摘出し，その 1 所に $1 / 4$ 針を以て

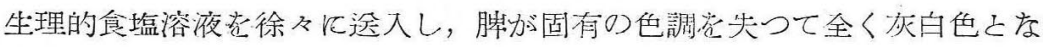
るまで根父よく食壏溶液を灌流させ，かくて全血液成分を除去したのち

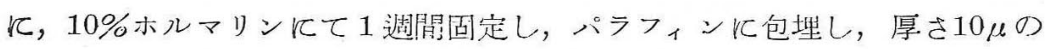
切片を作り，へマトキシリンとエオシンで染めた。 ての際全血液を失ふてて とによつて，脾の体積は大りに縮小するから，〕め対想亡して健常な二小 日鼠の脾を取り，乙れ莎者之同

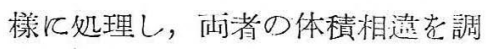
心゙，灌流脾の体積估を補正した。 脾では細網細胞の互の限品が明か でなんので(插図)，個々の細胞

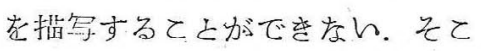
で細胞が網状に漸つている主主を

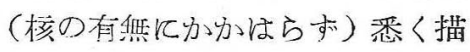
写プリズムにて $1 \mathrm{~mm}$ 目の方眼紙 の面積 $5 \times 5 \mathrm{~cm}$ のち的 1.000 倍 に拆大描写し，次にそれに含尔れ る核の数学算へた(切片の全厚に 亘つて). 措写せられた細胞網の実 面積 $\times 10 \mu$ (切片の厚さ）は脾の $50 \times 50 \times 10$ 立厅 $\mu$ 亿ある細絧細胞 の総体積であり，てれを核数で除 せば大略 1 個の細網細胞の体積が

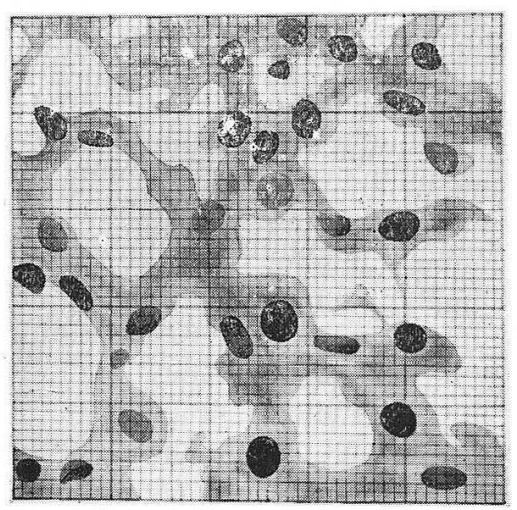

二十日鼠の灌流脾の網狀組織・チェ口1 ヂン创埋。 メマトキシリンーエオシン染 色. 切片の厚さ $10 \mu$, 拡大 1000 倍。

Das Retikulumgewe te von der durchspülten Milz der Maus. Eintettung in Zelloidin, Färbung mit Hämatoxylin-Eosin. Dicke des Schnittes $10 \mu$, Vergrößerung. $1,000 \times$. 得られる。(上文線組系参澹)

次に肝の Kupîīer 氏星細胞は生染せ㸚ば明確に認め難い。然し生染を。 行ふ.と全身の線組系が賦活せられて大い変化するから, 別の同大の二十 日鼠を生染して計測を行ひ，その值を本実験に用いた二十日鼠の肝の\&の

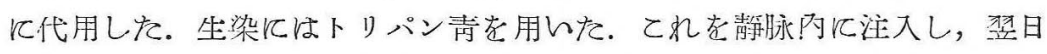
肝を取つてスーサ液で固定し，厚さ $15 \mu$ のチェロイヂン切片を作つた。 計測は脾之同樣力眼紙の面樍 $5 \times 5 \mathrm{~cm}$ 冈飞細胞老描年したが，細胞体積 の計测は，個々の細胞体の限界が明瞭なので，個ふの細胞の種々の高さに 
於ける形を描写し，その面積の平均值を求め，乙れに細胞の高さを乘じて 体積を求めた，注意すべきは細胞の黄の高さは，計測伯にキシロールバル サムの屈折菜1.52 进覕じたものなるととである。

\section{II. 檢 查の 成 績.}

\section{A. 線 組 系.}

表 1・二十日鼠存牛部の線組系細胞の総数とその総体積 $(\mathrm{cmm})$.

\begin{tabular}{|c|c|c|c|c|c|c|c|}
\hline & & 合 & 皮 & 箅 & 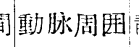 & 䢂脉周因 & 神経周圈 \\
\hline & 数 & & $6,137,500$ & 362,900 & o 74,700 & $88,200^{\prime}$ & 46,900 \\
\hline 䫒 & 体積 & & 11.44 & 0.40 & 0.11 & 0.12 & 0.06 \\
\hline 部面 & 数 & & $3,573,200$ & 587,400 & $\begin{array}{l}0 \quad 45,900 \\
\end{array}$ & 44,300 & 20,800 \\
\hline 珼 & 体積 & & 8.12 & 0.64 & 0.09 & 0.09 & 0.03 \\
\hline & 数 & & $14,817,200$ & 354,700 & 077,800 & 42,800 & 89,000 \\
\hline 胛部と上胶 & 体積 & & 31.69 & 0.34 & 0.23 & 0.07 & 0.14 \\
\hline & 数 & & $21,484,300$ & 148,100 & 0704,900 & 550,700 & 88,500 \\
\hline 䐎 & 体積 & & 41.78 & 0.23 & 1.57 & 1.32 & 0.11 \\
\hline 骨 般 部 & 数 & & $13,190,800$ & 207,900 & $0 \quad 114,400$ & 126,900 & 127,700 \\
\hline 管 皿 & 体積 & & 37.55 & 0.24 & 0.30 & 0.39 & 0.21 \\
\hline & 数 & & $16,278,800$ & 199,700 & $\begin{array}{lll}0 & 110,500\end{array}$ & 98,500 & 156,300 \\
\hline$r$ & 体積 & & 27.36 & 0.18 & 0.15 & 0.11 & 0.14 \\
\hline 琹 & 数 & & $3,216,400$ & 79,300 & $0 \quad 37,000$ & 18,600 & 29,900 \\
\hline 㲎 & 体積 & & 12.19 & 0.07 & 0.09 & 0.03 & 0.04 \\
\hline 口腔粘淖下 & 数 & $2,784,300$ & & & & & \\
\hline 中胫枯朕下 & 体積 & 2.36 & & & & & \\
\hline 千.粘哯下 & 数 & 372,700 & & & & & \\
\hline 百和朕下 & 体積 & 0.35 & & & & & \\
\hline 壬 穊 聞 & 数 & 128,900 & & & & & \\
\hline 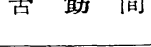 & 体積 & 0.13 & & & & & \\
\hline & 数 & 54,700 & & & & & \\
\hline 食直周四 & 体積 & 0.08 & & & & & \\
\hline 食道自己 & 数 & 747,200 & & & & & \\
\hline 食直目乙 & 体積 & 0.65 & & & & & \\
\hline & 数 & 65,300 & & & & & \\
\hline 父学周四 & 体積 & 0.06 & & & & & \\
\hline 気管自己 & $\begin{array}{l}\text { 数 } \\
\text { 体積 }\end{array}$ & $\begin{array}{c}1,185,300 \\
1.08\end{array}$ & & & & & \\
\hline
\end{tabular}

附記：線租系細胞の全数 $177,329,800$. その全体積 $364.68 \mathrm{cmm} .1$ 細胞の体積の本 均は $2056.5 \mathrm{c} \mu$.キシロールバルサムの屈折率1.52。 
右牛身の皮下，筋間，血管周圍，神経周圍，諸器官の粘膜下，気管自 己，気管周圍，食道自己，食道周園の結合組織飞就さ，上述の方法で得た 計測値を，縉めて表 1 亿揭げを.

云ふっでもないが，切片に於て平たん結織細胞の面から見ての計測は容 易で西るが，その面に垂直または斜の断面からの計測は，前記の法によつ ても起しく困難，時に不能であるから，第 1 表の細胞の計測值は，極めて 嚴格には正確とは五へないけれども，んまの㸴究目的には十分であるてと 灰附言する。

\section{B. 網內 系。}

自然の脾の体積 $\mathrm{V}$ 亡生理的食塩溶液を以て灌流して全血液亡細網細胞の 派生細胞の大部分苍駆遂した脾の体積V'亡には，チェロイヂン包埋直前

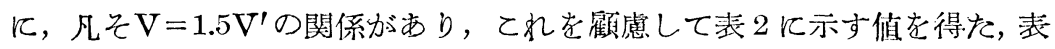
には肝の Kupffor 氏星細胞の計測值をも揭げた。

表 2 ．二十日鼠の脾と肝の網內采細胞の総数とその総体積.

\begin{tabular}{|c|c|c|}
\hline 脾 の 細 網 細 胞 & 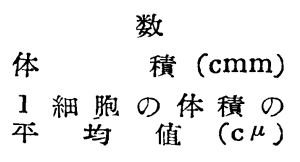 & $\begin{array}{r}56,329,000 \\
26.22 \\
465.5\end{array}$ \\
\hline 肝の Kupffer 氏 細胞 & $\begin{array}{cc} & \text { 数 } \\
\text { 体 } & \text { 積 }(\mathrm{cmm}) \\
1 \text { 細胞 } & \text { 体 積 } \\
\text { 平均 值 }(\mathrm{c} \mu)\end{array}$ & $\begin{array}{r}107,600,200 \\
16.72 \\
155.4\end{array}$ \\
\hline
\end{tabular}

附記. 脾の体積 $65 \mathrm{cmm}$, 肝の体積 $750 \mathrm{cmm}$, キシロールバルサムの屈折率 1.52 .

\section{III. 考 察.}

仙表の計測值の考察には材料の処理亡計測の方法をよく考虑しなければ ならなん，乙こに檢查した線組系は身体にあるものの全部ではなんが，そ の大部分であり，安た網內系は脾の細網細胞之肝の星細胞だけであるが， ての耐器官の網勺系は身体に於んて主要のものである。 また計測け極めて 精密よは云へなんけれども，材料の性質上，乙の程度は許されてよんと思 ふ. 両表を比較して知られる重要な事㖽は，

1. 胸部, 腹部, 骨盤部の门臟亡, 脳, 脊髓, 眼球, 鼻腔壁苍除んた全 身の線組系の細胞 (線維細胞, 線組球, 組織球, 單核球) の総数は，1億 7700 万余，脾亡肝飞ある絧內系の細胞（細絧細胞टKupffer 氏星細胞）の 総数は，1億6400万余で，汕者㾟ぼ相匹敵する。

2.しかし細胞の総体積よ, 線組亲に $365 \mathrm{cmm}$ で, 实に脾の細絧細胞之 
肝の星細胞の $43 \mathrm{cmm}$ の約 8 倍である. 因みに沢近 (16。う) は家鬼の脾で， $1 \mathrm{cmm}$ てある細絧細胞亡その派生細胞の総数忍 660.000 で，その総体積 が $0.273 \mathrm{cmm}$ であるとと学見た。

故に全身の画系の類似の機能に関しては，細胞の容積が格段に勝る線組 系の方の能力が遥か、に大をんであらう.

\section{IV. 結 語.}

生後約 2 月の健常雄性二十日鼠飞於ける全線組系の大部分之膆亡肝の網 內系の細胞の計測を試みた。

胸, 腹, 骨盤部の內臟亡, 脑, 脊髓, 眼球, 鼻腔壁を除々た全身の線組 系の細胞の総数は 1 億 7700 万余であつて, 脾の細網細胞之肝の星細胞の総数 の1億6400万に庄ぼ等しく，細胞の全体積は前者に $365 \mathrm{cmm}$, 後者に $43 \mathrm{cmm}$ で，前者が約 8 倍である，線組系細肘はまだ檢しなん諸何臟にある線組系 細胞を加一れば，数之体積に於んて約 4 分 1 增すであらうと想像せられ， 線組系が免疫亡物質代謝に於んて甚だ重要なことが賽はれる。

\section{Autoreferat.}

Der größte Teil der Zellen des fibrohistiozytären Systems im ganzen Körper und des Retikuloendothelialsystems in der Leber (Sternzellen) und Milz (aber nur Retikulumzellen) der erwachsenen Maus wurden histometrisch untersucht. Die Gesamtzahl der Zellen im fibrohistiozytären System (etwa 177,000,000) ist, wenn man von den Eingeweiden der Brust, des Bauches und des Beckens, dem Gehirn, dem Rückenmark, dem Angapfel und der Nasenhöhlenwand absieht, fast eire gleiche mit derjenigen. der genannten Zallon des Retikuloendothelialsystems in der Milz und der Leber (wetwa 164,000,000). Das Gesamvtolumen der Zellen ist bei dem ersteren System etwa $365 \mathrm{cmm}$ und bei dem leizteren etwa $43 \mathrm{cmm}$. Das Gesamtvolumen des fibrohistiozytären Systems ist also etwa achtmal größer. Wenn man die fibrohistiozytären Zellen in den noch nicht untersuchten Eingeweiden zu den oben genannten addiert, so nehmen vielleicht die Zahl und das Volumen des fibrohistiozytären Systems noch um etwa ein Viertel zu. Daraus darf man sicherlich schließen، daß das fibrohistiozytäre System von überaus großem Gesamtvolumen bei den Immunitätsvorgängen und dem Stoffwechsel eine sehr große Rolle spielt. 


\section{文献。}

Lewis, W. H. : Macro hages and other cells of the deel fascia of the thigh of the rat. Contr. to Embryol. 20 (1929). - Sawachika, H.: Effests of fibrohistiocytc system extract on bacteria. Arch. hist. jay. 1 (1950): 